August 25, 2003

\title{
Why are small firms different? Managers' views
}

\author{
Jonas Agell ${ }^{*}$
}

\begin{abstract}
Do incentives in small organizations differ from those in large ones? This paper uses a representative survey of compensation managers to shed light on the issues. I find that (i) small establishments rely less on pecuniary incentives, and have a significantly more hostile attitude towards incentive schemes based on competition and relative rewards; (ii) large units are more vulnerable to mechanisms of efficiency wages, effects that remain even as I control for differences in monitoring ability; (iii) large units are more prone to indicate that negative reciprocity is important, and that their employees care about relative pay. I argue that these findings fit with behavioral stories of incentives and motivation, in particular those stressing group interaction effects, inequity aversion and gift exchange.
\end{abstract}

Keywords: firm-size effect, motivation, relative pay, field-survey, matched data JEL Codes: J30, J41

\footnotetext{
* Stockholm University and CESifo; address: Department of Economics, Stockholm University, SE-106 91 Stockholm; email: JA@ne.su.se. I am grateful to Martin Dufwenberg for helpful suggestions.
} 


\section{Introduction}

A voluminous literature has documented that large employers pay higher wages than smaller ones, and that this wage premium remains even after controlling for observable worker-firm characteristics. The size effect is numerically large; Brown, Hamilton and Medoff (1990) show that employees in US companies with more than 500 employees earn 35 percent more than those in companies with less than 500 employees, and Troske (1999) observes that the size wage gap may explain a large share of overall wage inequality in the United States. The wage effect of employer size has been documented in a number of countries, and in environments with very different institutional arrangements. ${ }^{1}$

As noted by Groshen (1991) understanding the source of employer differences in pay is central for understanding the distribution of income and for designing policies towards inequity and pay discrimination. Yet, the literature has been less successful in explaining why the wage policies of large employers differ from those of smaller ones. ${ }^{2}$ This paper uses a new data source to shed light on the nature and sources of size-effects in pay policy, namely a survey of a representative sample of professional wage setters.

An interview approach has some advantages. Standard data sources typically contain a lot of information about worker and establishment characteristics, but they do not contain information about the objectives and constraints of managers and workers. For example, do larger units pay higher wages because efficiency wage mechanisms matter more in larger units, or do they pay higher wages because labor productivity is higher in larger establishments (i.e. a competitive explanation)? Using conventional data it is not easy to

\footnotetext{
${ }^{1}$ Brown and Medoff (1989), Groschen (1991), Oi and Idson (1999), and Troske (1999) report and summarizes results for the US. Arai (2003) report results for Sweden. Albaek et al. (1998) present results for the Nordic countries, and provide references to studies for other non US-countries.

${ }^{2}$ Brown and Medoff (1989, p. 1056) note "that the size-wage differential appears to be both sizeable and omnipresent", and yet concludes that their analysis leaves them "uncomfortably unable to explain it". More recently, Troske (1999) uses matched worker-firm data to examine several theoretical explanations for the sizewage premium. Though Troske finds that many theories can account for some of the size premium, he
} 
differentiate between these propositions. However, by asking direct questions to the responsible manager about the objectives behind a firm's wage policy one may hope to distinguish between mechanisms. Furthermore, many theories of pay and motivation involve non-observables, which make it very difficult to implement traditional quantitative methods. ${ }^{3}$

I report several regularities that I have not seen documented in the previous literature. Some of these fit with standard agency models of employee motivation, but there are also regularities that are difficult to explain without bringing in behavioral arguments, centering on concepts like group interaction effects, inequity aversion and negative reciprocity. Behavioral mechanisms may explain why the smaller units in our sample have more compressed pay distributions, and why they appear to be able to motivate their employees without using highpowered performance incentives. Behavioral mechanisms may also explain why managers in smaller organizations bother less about negative reciprocity, and why relative wage comparisons constitute a less important constraint in the local pay bargain.

The next section discusses our survey design, and reports some basic correlations. Section 3 presents our findings, and Section 4 concludes.

\section{Our sample and survey design, and some basic correlations ${ }^{4}$}

Our random sample consists of 1200 establishments, divided among four sectors

(manufacturing, unskilled services, skilled services, and public administration), and three size

\footnotetext{
concludes, "in the end, there still remains a large, significant, and unexplained premium paid to workers in large plants and firms" (Troske (1999, p. 16)).

${ }^{3}$ There are also some disadvantages; for example, respondents may have an incentive to dress-up their answers. In our case, respondents were promised anonymity, and most of our questions concern issues where it is hard to see that respondents have an incentive to conceal the truth. For economists arguing the usefulness of interviews and related field research, see e.g. Blinder (1991), Bewley (1999) and Helper (2000). In the last decade interview studies have become commonplace among macroeconomists studying wage rigidity, see e.g. Blinder and Choi (1990), Agell and Lundborg (1995, 2003), Campbell and Kamlani (1997) and Bewley (1999). However, the interview approach still appears to be a quite underutilized method in the literature on employee motivation. ${ }^{4}$ The survey - implemented in cooperation with Statistics Sweden - was specifically designed to shed light on the reasons for wage rigidity. Several of the questions also have a bearing on more general issues in the economics of personnel, and it is this part of the survey that I exploit in the present paper. Agell and Bennmarker (2002) provide a detailed documentation, including an English translation of the questionnaire.
} 
categories (5-19 employees, 20-99 employees, and more than 99 employees). ${ }^{5}$ Since we wanted to explore pay incentives at the level of the individual plant, and as managers at the head office of large company might know less about pay at the local level, we chose the establishment rather than the firm as our sampling unit. We took many steps to reduce nonresponse bias, and we obtained replies from 885 establishments, implying a very high response rate of 75.1 percent. No less than 300 of the responding establishments belong in the smallest size category, with less than 20 employees. ${ }^{6}$

Our questionnaire was sent out in March 1999, and after three reminders the data gathering was called off in May. All questions are closed ones, and we asked respondents to indicate their replies on an ordinal scale, with four or five options. An accompanying letter promised that respondents' anonymity would be preserved, and we asked for the cooperation from the human resource manager, or from someone with corresponding functions. Most of our questions concern quite concrete issues of work and pay, and we emphasized that we were interested in understanding practices at the respondent's own unit. Like Bewley (1999) we tried to avoid hypothetical questions, and questions that required respondents to assess the general equilibrium implications of firm-level wage setting.

Our background information about responding units comes from three sources. First, the business register of Statistics Sweden contains information about the geographical location of the establishment, sectoral classification, and number of employees. Second, our survey asked about union density, pay systems and employment contracts. Third, via their tax

\footnotetext{
${ }^{5}$ Manufacturing was included as a natural benchmark for our analysis. Skilled services (computer consultants, law firms, architect's offices, etc) is of interest because it represents a segment of the labor market with complicated jobs, and where models of work-life incentives and tournaments might be of particular relevance. Unskilled services (hotels and restaurants) is a sector with simple jobs, where the forces of demand and supply ought to matter a lot. Since we also wanted to pay attention to differences between profit maximizing units and those that operate under other constraints we also included public sector administration.

${ }^{6}$ The response rate in the smallest size category was 73.8 percent in manufacturing, 45.9 percent in unskilled services, 69.7 percent in skilled services, and 79.2 percent in public administration. Agell and Bennmarker (2002) present an analysis of non-response bias. Under the assumption that non-responders would have answered in the same way as the late responders (who replied only after one or more reminders), they estimate the potential magnitude of the non-response bias, and conclude that it is negligible.
} 
and education registers Statistics Sweden provided us with data on the characteristics of the employees of responding units. Thus, for all but a handful of units we have detailed demographic and educational information about employees. For each plant we also have information about average and median earnings.

Table 1 reports some basic establishment-size correlations, obtained from estimating plant-level equations where we include a range of controls for worker-firm characteristics. In the first column the endogenous variable is the log of average earnings. In the second column the endogenous variable is the skewness of the plant-level earnings distribution, measured as the distance between mean and median earnings, divided by the mean; I interpret this as a crude measure of earnings inequality. I measure size by the number of employees per establishment, i.e. size is treated as a continuous variable.

The size-elasticities reported in the first column are quite large, and well in line with those reported for the Nordic countries by Albaek et al (1998), and even larger than those reported for Sweden by Arai (2003) (unlike us these studies use data on individual employees; they also use data from earlier time periods). The basic control variables in row 1 include the worker characteristics that would appear in an ordinary wage equation (i.e. we control for age, schooling, gender, immigrant status, etc). Our basic controls also include the share of employees on a permanent employment contract, ${ }^{7}$ and dummies for geographical location. Row 2 adds eight dummies controlling for the establishment's sectoral affiliation, and one dummy indicating whether it belongs to a multi-unit firm. Rows 3 and 4 add self-reported measures of union density and management's ability to judge work performance (we discuss the latter measure further below). Obviously, there remains a significant size earnings premium even as we control for various worker and establishment specific factors, and

\footnotetext{
${ }^{7}$ The idea behind the inclusion of this variable is that workers' bargaining power ought to be an increasing function of the share of employees with secure jobs. The share of employees on a permanent contract is probably also correlated with the stock of firm-specific skills. In firms where long-term employment relationships are common, there is a stronger incentive to invest resources in firm-specific skill formation.
} 
introduce measures of institutional involvement (union density) and monitoring ability. Thus, our sample replicates the kind of size-earnings correlations reported in previous studies.

The second column shows that there also appears to be a statistical correlation between establishment-size and wage inequality, as measured by our measure of skewness. On average, larger establishments have a more skewed earnings distribution, However, the $t$ ratios are now considerably lower, and it is only in rows 1, 3 and 4 that the coefficient on the size variable is significant at the five-percent level. We view this as moderately strong evidence that wage inequality is larger in larger establishments. Below, we report substantial evidence that managers in larger establishments are more prone to exploit incentives based on performance pay and relative rewards, and that managers in smaller establishments tend to believe that incentives based on relative pay and competition among employees have counterproductive effects on employee motivation.

\section{How to motivate: Managers' views}

\subsection{Ability to judge work performance}

A basic issue in models of pay and motivation is to what extent managers can accurately observe and evaluate work performance. Indeed, some authors have argued that the very existence of a size-earnings premium can be traced to the fact that larger establishments find it more difficult to monitor their workers, see e.g. Garen (1985) and Bulow and Summers (1986). When we asked "to what extent can you evaluate whether a specific employee performs satisfactorily on the job?", 50.7 percent indicated that they could evaluate performance to a very great performance", while 49.3 percent were less than certain about performance. It is noteworthy that these percentages did not differ very much across sectors. In manufacturing, and in skilled and unskilled services, the percentage of managers indicating that they could evaluate work performance to a very great extent was 55.0, 56.7 and 57.1 
percent, respectively. Public administration is the outlier; here, only 37.5 percent of managers indicated that they could evaluate work performance to a very great extent.

Is it more difficult to appraise work performance in a larger organization? Table 2, column 1 , shows our analysis. Our question on the ability to evaluate performance had four response options, and I regressed these answers on the independent variables shown in Table 1, using an ordered logit model. The first row shows that the coefficient on establishment size is negative and highly significant $(p$-value $<.01)$ in a regression where we use our basic regressor set, and the second and third row show that the significance levels increase even further as we add controls for sectoral affiliation and union density. Thus, it appears that managers in smaller establishments have a greater ability to judge work performance.

When management can fully evaluate work performance the textbook recommends that piece rates should be the preferred tool of motivation, i.e. a method that creates a direct link between worker output and pay. However, even though many managers indicated that they could judge work performance to a great extent, piece rates were rarely used. When we asked what percentages of the workforce that was covered by "some form of piece rate system", no less than 95.3 percent of managers responded that less than 10 percent (which was our lowest response category) of their employees were covered by such a system. Moreover, the incidence of piece rates did not differ between establishments who could/could not evaluate work performance; in both groups slightly more than 95 percent of respondents indicated that less than 10 percent of their employees were on piece rates.

\subsection{How to motivate I: performance pay}

Economic theory suggests several reasons why firms may avoid using high-powered performance incentives like piece rates. First, in an environment with multitasking, pay schemes based on tightly specified performance may induce workers to neglect tasks that are 
less easy to measure (Holmstrom and Milgrom (1994)). Second, when workers are uncertain about their future productivity the efficient compensation package will contain an insurance element that compresses the pay distribution; Stiglitz (1975) thus shows that risk averse workers can be expected to prefer time rates to piece rates. Third, tournament theory deals with incentive design in settings when firms can only evaluate relative performance, and it suggests that firms can use pay differentials and competition for higher paid career jobs to replicate the outcome of piece rates; see Lazear and Rosen (1981). But there are also models suggesting that pay according to relative performance provides workers with an incentive to sabotage the effort of other workers, and that firms therefore have an incentive to compress the pay distribution; see e.g. Lazear (1989). ${ }^{8}$

The agency models of the preceding paragraph assume that workers only care about their own income, and that they need pecuniary incentives to overcome their distaste for effort. However, recent advances in behavioral economics - drawing on insights from e.g. psychology and sociology - strongly suggest that these assumptions need to be qualified. ${ }^{9}$ People often seem to care about relative income, and have a preference for fairness and a distaste for inequity. Social norms and group interactions may stimulate work effort and cooperation even in the absence of formal incentive contracts. And workers who feel unjustly treated may retaliate by reducing effort (i.e. gift exchange or negative reciprocity). For these reasons a firm may in fact find it optimal to avoid using completely specified incentive contracts, and to design reward schemes that respond to the fairness perceptions of workers.

What tools do managers use to motivate their employees? We asked them to indicate whether the following devices were important tools at their own establishment: (i) supervision and monitoring, (ii) career ladders, (iii) performance-related pay, and (iv) measures to promote good management-worker relations. In asking about the latter we

\footnotetext{
${ }^{8}$ For a related analysis, see Priks (2003).
} 
provided examples of the techniques that according to management texts should be used to stimulate good management-worker relations, like making the job interesting, delegating authority and communicating the goals of the firm. An overwhelming majority ranked good relations as a much more important motivational tool than the standard tools discussed in the agency literature, see Table 3. In all sectors 63.9 percent indicated that they relied on good management-worker relations to a great or fairly great extent, while only 15 percent indicated the same about supervision and monitoring. ${ }^{10}$ Respondents in skilled services pointed to the importance of career ladders, a device that plays a key role in models of tournaments and work-life incentives.

Table 2, columns 2-5, shows our econometric analysis of size related differences in managers' use of different motivational tools. Establishment size does not seem to matter for the importance attached to either monitoring and supervision (column 2) or good management-worker relations (column 5). But both the willingness to use performance pay (column 3) and the importance attached to career ladders (column 4) increases with establishment size. These partial correlations between size and incentive pay remain statistically significant at the one-percent level (or more) as we bring in finer controls for sectoral affiliation (row 2) and unionization (row 3). Moreover, the partial correlations do not change as we bring in our control for ability to judge work performance in row 4; thus, our finding that larger establishments make more frequent use of performance pay and career ladders does not seem to be related to the fact that small and large establishments have unequal information about work performance.

\footnotetext{
${ }^{9}$ For some references, and additional guidance to the literature, see e.g. Akerlof $(1980,1982)$, Encinosa, Gaynor and Rebitzer (1997), Fehr and Schmidt (1999), Gneezy and Rustichini (2000) and Fehr and Gächter (2002).

${ }^{10}$ In comparing these numbers it must be noted that there is an obvious risk that managers' choice between "good management-worker relations" and "supervision and monitoring" is biased by the fact that the former option has such a friendly ring. Agell and Lundborg (1995, 2002), Bewley (1999) and Campbell and Kamlani (1997) are other studies reporting that compensation managers often deny the relevance of the motivational tools assumed in e.g. the canonical shirking model of Shapiro and Stiglitz (1984).
} 
I also computed the Spearman rank correlations between managers' responses, and found that there was a positive association between firms' uses of incentive pay (career ladders and performance pay) and soft incentives (good management-worker relations). The Spearman correlations between career tracks and good relations, and between performance pay and good relations, are 0.30 and 0.14 ( $p$-value $<.0001$ for both correlations). One way of thinking about these correlations is with reference to recent work suggesting that incentive pay may tend to crowd out voluntary cooperation and "intrinsic motivation", see Gneezy and Rustichini (2000) and Fehr and Gächter (2002), and the references cited therein. To the extent that incentive pay has a negative side effect on intrinsic motivation, firms that rely on incentive pay to a great extent may have much to gain from also making extensive use of soft incentives that try to promote closer workerfirm identification.

In two follow-up questions we asked managers to indicate whether large pay differentials, or fierce competition between employees, had - or would have - positive or negative effects on work motivation at their own unit. The response distributions were bimodal: 36.1 percent thought that large pay differentials were detrimental, 50.9 percent that they were beneficial, and 13 percent that the negative and positive effects cancelled out. Thirty-seven percent indicated that competition between employees was largely detrimental, 44.8 percent that it was largely beneficial, and the remaining 18.2 percent that the costs balanced the benefits.

Does establishment size matter for managers' attitudes towards large pay differentials and fierce competition? Based on the more frequent use of incentive pay in larger organizations one would certainly expect an answer in the affirmative, and this is also what we find. Table 2, column 6 , shows that the partial correlation between establishment size and managers' assessment of the benefits from large pay differentials is 
always positive, and statistically significant at the one-percent level. This robust partial correlation is consistent with our finding in Table 1, column 2, that larger establishments tend to have more skewed earnings distribution. The partial correlation between establishment size and managers' assessment of the benefits from fierce competition in column 7 is also positive, but only statistically significant at the ten-percent level.

One way of interpreting these results is with reference to the "sabotage-model" of Lazear (1989), which shows that the potential benefits from creating a work environment where relative rewards play a decisive role depend crucially on firms' ability to match workers with appropriate personalities. To the extent that creating such appropriate matches is easier in a large establishment, one would expect that managers in large units have a more positive attitude towards incentives based on relative performance. But it is also possible to interpret these results in behavioral terms. It seems reasonable to assume that there is a closer proximity between workers, and between workers and management, in smaller establishments. In this environment, worker group norms and peer pressure can be expected to be quite decisive motivational factors. To the extent that (at least some) workers are inequity averse, or have a preference for fairness, maintaining these beneficial group interactions may require that firms do not use incentives that create pay inequity. ${ }^{11}$

\subsection{How to motivate II: Negative reciprocity and the outside option}

Under certain conditions incentive pay in the form of e.g. piece rates and promotion tournaments may lead to a first-best optimum. In environments where these instruments are unavailable - for example because of imperfect capital markets, binding fairness norms, etc. management may rather prefer to pay efficiency wages. Some of our questions were specifically designed to explore managers' reactions to popular models of efficiency wages.

\footnotetext{
${ }^{11}$ For an interesting theoretical analysis along these lines, see Encinosa, Gaynor and Rebitzer (1997).
} 
Most efficiency wage models predict that changes in external wages (or the outside option) have an impact on work effort. This is true of the canonical shirking model of Shapiro and Stiglitz (1984), and it also applies for those versions of the gift-exchange model of Akerlof (1982) in which workers' norms of comparison extend to workers in other firms. To assess the relevance of these models we simply asked: "How do you think that the work effort of your employees would be affected if wages/salaries increased in comparable companies or organizations, but stayed the same at your unit?". No less than 581 out of 882 responding managers (65.9 percent) thought that higher external wages would lower effort at their own establishment.

A recent experimental literature suggests that negative reciprocity is an important motivational factor, and that the risk that disgruntled workers will retaliate by reducing effort makes firms willing to pay high wages, see e.g. Fehr, Kirchsteiger and Riedl (1993). We asked a question that tried to capture the essence of negative reciprocity: "In your opinion, do those of your employees who are dissatisfied with their pay normally reduce effort?" Fortynine percent of our respondents (427 managers) answered in the affirmative, 28.9 percent answered that such a response was possible but not common, while 22.1 percent ruled out the possibility altogether.

The labour turnover model suggests that firms have an incentive to pay high wages to avoid costly labor turnover. To investigate whether this was an issue we asked: "In your opinion, do those of your employees who are dissatisfied with their pay normally seek employment elsewhere?". Out of 880 responding managers, 58.5 percent replied in the affirmative, 29.4 percent indicated that voluntary turnover was possible but uncommon, while 12.1 percent ruled out this possibility altogether.

Based on these responses it certainly appears that most managers view the outside option, negative reciprocity and the risk of voluntary turnover as important constraints on 
their wage policy. Table 4, columns 1-3, presents our analysis of size-related differences in managers' attitudes towards these mechanisms. The coefficient on establishment size is significant and estimated with very high precision in columns 1 and 2. Managers in large establishments are more likely to identify a negative link between effort and external pay, and more likely to indicate that negative reciprocity is an important issue. These results, suggesting that managers in larger establishments perceive a greater incentive to pay efficiency wages, is consistent with the result shown in Table 1 that employees in large firms have higher earnings. Finally, size does not appear to matter for the perceived risk of voluntary turnover.

A conventional way of explaining our findings goes as follows. Since managers in larger establishments find it more difficult to judge work performance (see Table 2, column 1), the shirking model would lead us to believe that effort in larger units is more responsive to external pay. We would also expect large units to find it more difficult to prevent acts of negative reciprocity. However, the specification test in row 4 suggests that this explanation is too simple. If the size effects in columns 1 and 2 primarily capture the inferior monitoring capacity of large units they would not remain significant when we add direct measures of monitoring capacity to the estimating equation. But row 4 shows that the coefficient on the size variable remains significant at the one-percent level in both columns. We conclude that our findings that external pay and negative reciprocity matter more for effort in larger units is not primarily due to the insufficient monitoring capacity of larger establishments. Instead, both results appear to fit with the idea that peer pressure and social work norms may play a more important role in disciplining behavior in smaller establishments. 


\subsection{Pay norms and pay comparisons}

Our maintained hypothesis during much of the preceding discussion is that workers care about relative pay, and that this may have real consequences for effort and work norms. Previous survey studies - see e.g. Agell and Lundborg (1995, 2003) and Bewley (1999) - suggest that compensation managers do believe that their employees pay a lot of attention to internal and external wage relativities. Our managers responded in a similar manner. Across all strata, 47.3 percent indicated that internal wage comparisons “' always' or 'frequently' played an important role in the local wage bargain," and 41.8 percent said the same about external wage relativities. $^{12}$

Unlike Agell and Lundborg (1995, 2003) and Bewley (1999) we have access to a representative sample of managers in both small and large establishments, which means that we can push deeper when it comes to exploring the role of establishment size. Table 4, columns 4-5, shows that both internal and external wage comparisons appear to play a greater role in larger establishments. In column 4 (internal wage comparisons) the coefficient on our size variable is always statistically significant at the 0.1 percent level. The coefficient on establishment size in column 5 (external wage comparisons) drops considerably when we add union density in row 3 (union density is significantly higher in larger establishments), but it remains statistically significant at the five-percent level.

Thus, employees in larger establishments seem to care more about wage relativities than employees in smaller establishments. This result fits with our finding that efficiency wage mechanisms involving the outside option play a greater role in large establishments. It also fits with our conjecture that group interactions and peer pressure may play a greater role than incentive pay in smaller establishments. Compare the managers in (the hypothetical)

\footnotetext{
${ }^{12}$ Bewley (1999) finds that internal wages play a much more important role than external wages. But he also notes that the precision of the information about external pay appears to be higher among workers in unionized firms. In line with this conclusion, Agell and Bennmarker (2002) show that there is a robust partial correlation between union density and the intensity of external wage comparisons in the Swedish survey data.
} 
establishments Alfa (small establishment) and Beta (large establishment). Alfa has coordinated on an equilibrium where social pressure rather than incentive pay is the device that generates effort, while Beta has coordinated on an equilibrium where relative pay rather than group interactions is the primary effort device. If asked to respond to this survey, the compensation manager in Beta will be more prone to indicate that employees care about relative pay.

\section{Conclusions}

Our survey of a representative sample of professional wage setters suggests that smaller establishments arrange their incentive systems in ways that differ substantially from larger establishments. I have argued that most of these effects lend themselves quite naturally to interpretations along behavioral lines, stressing group interactions, inequity aversion and gift exchange. These mechanisms may explain why smaller establishments appear to have more compressed pay distributions, and they may also explain why larger establishments find it worthwhile to pay higher than average wages.

I acknowledge the preliminary nature of these interpretations. I also acknowledge that there are refined agency theories which might go some way towards rationalizing why e.g. smaller establishments have a more negative attitude to performance pay, and why negative reciprocity appears to matter less in the same establishments. In trying to discriminate between theories, students of incentives in the labor market have much to gain from continued interactions with professional compensation managers. 
Table 1. Basic establishment-size effects; coefficient on $\ln$ (No. of employees)

\begin{tabular}{ll}
\hline Explanatory variables & Dependent variables
\end{tabular}

\begin{tabular}{lcc}
\hline & $\ln$ (average earnings) & skewness \\
\hline 1. Basic variables & $0.026^{* *}$ & $0.008^{* *}$ \\
& $(0.008)$ & $(0.004)$ \\
2. Adding dummies for two-digit industry & $0.033^{* *}$ & $0.007 *$ \\
affiliation and multi-unit firm & $(0.009)$ & $(0.004)$ \\
3. Adding union density & $0.043 * *$ & $0.010^{* *}$ \\
& $(0.009)$ & $(0.005)$ \\
4. Adding control for ability to evaluate work & $0.044^{* *}$ & $0.010^{* *}$ \\
performance & $(0.009)$ & $(0.005)$ \\
\hline
\end{tabular}

performance

Depending on the set of conditioning variables, the no. of observations vary between 823 and 839 . Basic variables include: dummy variables for geographical location, share of female employees, share of non-Nordic employees, share of employees with only elementary education, share of employees with university education, average age of employees, square of average age of employees, and share of employees on permanent employment contract. The precise two-digit industry codes are presented in Agell and Bennmarker (2002). Union density is the (self-reported) share of employees that belong to a union. Our control for ability to measure work performance is discussed in Section 3. 
Table 2. Establishment-size, performance evaluation and choice of motivational tools; coefficient on In(No. of employees), (ordered logit regression)

\begin{tabular}{|c|c|c|c|c|c|c|c|}
\hline \multirow[t]{2}{*}{ Explanatory variables } & \multicolumn{7}{|c|}{ Dependent variables } \\
\hline & $\begin{array}{l}\text { Can evaluate } \\
\text { individual } \\
\text { work } \\
\text { performance }\end{array}$ & $\begin{array}{c}\text { Monitoring } \\
\text { and } \\
\text { supervision } \\
\text { used intensely }\end{array}$ & $\begin{array}{l}\text { Performance } \\
\text { related pay } \\
\text { used } \\
\text { intensively }\end{array}$ & $\begin{array}{c}\text { Career tracks } \\
\text { used } \\
\text { intensively }\end{array}$ & $\begin{array}{c}\text { Good } \\
\text { management- } \\
\text { worker } \\
\text { relations used } \\
\text { intensively } \\
\end{array}$ & $\begin{array}{c}\text { Wage } \\
\text { differentials } \\
\text { are good for } \\
\text { work } \\
\text { motivation } \\
\end{array}$ & $\begin{array}{l}\text { Competition is } \\
\text { good for work } \\
\text { motivation }\end{array}$ \\
\hline & 1 & 2 & 3 & 4 & 5 & 6 & 7 \\
\hline 1. Basic variables & $\begin{array}{l}0.026 * * \\
(0.008)\end{array}$ & $\begin{array}{c}0.016 \\
(0.050)\end{array}$ & $\begin{array}{c}0.147 * * \\
(0.051)\end{array}$ & $\begin{array}{l}0.249 * * \\
(0.050)\end{array}$ & $\begin{array}{c}0.054 \\
(0.050)\end{array}$ & $\begin{array}{l}0.259 * * \\
(0.052)\end{array}$ & $\begin{array}{l}0.100^{*} \\
(0.050)\end{array}$ \\
\hline 2. Adding dummies for two-digit industry & $0.033 * *$ & 0.040 & $0.181 * *$ & $0.213 * *$ & 0.008 & $0.268 * *$ & $0.092 *$ \\
\hline affiliation and multi-unit firm & $(0.009)$ & $(0.054)$ & $(0.056)$ & $(0.054)$ & $(0.054)$ & $(0.056)$ & $(0.054)$ \\
\hline 3. Adding union density & $\begin{array}{c}0.043 * * \\
(0.009)\end{array}$ & $\begin{array}{c}0.046 \\
(0.056)\end{array}$ & $\begin{array}{c}0.171^{* *} \\
(0.059)\end{array}$ & $\begin{array}{c}0.240 * * \\
(0.056)\end{array}$ & $\begin{array}{c}0.012 \\
(0.056)\end{array}$ & $\begin{array}{c}0.267 * * \\
(0.059)\end{array}$ & $\begin{array}{l}0.103^{*} \\
(0.057)\end{array}$ \\
\hline $\begin{array}{l}\text { 4. Adding control for ability to evaluate work } \\
\text { performance }\end{array}$ & -- & -- & $\begin{array}{c}0.177 * * \\
(0.060)\end{array}$ & $\begin{array}{c}0.252 * * \\
(0.056)\end{array}$ & $\begin{array}{c}0.035 \\
(0.057)\end{array}$ & $\begin{array}{c}0.275^{* *} \\
(0.059)\end{array}$ & $\begin{array}{l}0.106^{*} \\
(0.057)\end{array}$ \\
\hline
\end{tabular}

Notes: * denotes significance at $10 \%, * *$ significance at $5 \%$. The standard errors are shown in parenthesis. The explanatory variables are explained in the notes to Table 1. 
Table 3. Importance of different motivational tools in different sectors

Motivational tool

Percentage of managers that use the motivational tool to a "great" or "fairly great" extent

Manufacturing $\begin{gathered}\text { Unskilled } \\ \text { services }\end{gathered}$ Skilled services $\begin{gathered}\text { Public } \\ \text { administration }\end{gathered}$

\begin{tabular}{lcccc}
\hline $\begin{array}{l}\text { Supervision and } \\
\text { monitoring }\end{array}$ & 13.0 & 27.9 & 18.4 & 7.0 \\
$\begin{array}{l}\text { Career ladders } \\
\text { Performance related pay }\end{array}$ & 17.1 & 34.3 & 40.7 & 13.7 \\
$\begin{array}{l}\text { Good-management } \\
\text { worker relations }\end{array}$ & 15.0 & 10.0 & 16.7 & 5.9 \\
\hline
\end{tabular}


Table 4. Establishment-size, negative reciprocity and wage norms; coefficient on $\ln$ (No. of employees), (ordered logit regression)

\begin{tabular}{|c|c|c|c|c|c|}
\hline \multirow[t]{2}{*}{ Explanatory variables } & \multicolumn{5}{|c|}{ Dependent variables } \\
\hline & $\begin{array}{l}\text { Higher external } \\
\text { wages lower } \\
\text { employee effort }\end{array}$ & $\begin{array}{l}\text { Employees who feel } \\
\text { underpaid normally } \\
\text { reduce effort? }\end{array}$ & $\begin{array}{l}\text { Employees who feel } \\
\text { underpaid normally } \\
\text { seek job elsewhere }\end{array}$ & $\begin{array}{l}\text { Internal wage } \\
\text { structure plays } \\
\text { important role in } \\
\text { wage bargain }\end{array}$ & $\begin{array}{l}\text { External wages play } \\
\text { important role in } \\
\text { wage bargain }\end{array}$ \\
\hline & 1 & 2 & 3 & 4 & 5 \\
\hline 1. Basic variables & $\begin{array}{c}0.236^{* *} \\
(0.053)\end{array}$ & $\begin{array}{c}0.226 * * \\
(0.049)\end{array}$ & $\begin{array}{c}0.028 \\
(0.049)\end{array}$ & $\begin{array}{l}0.414 * * \\
(0.050)\end{array}$ & $\begin{array}{l}0.216^{* *} \\
(0.049)\end{array}$ \\
\hline 2. Adding dummies for two-digit industry & $0.198 * *$ & $0.219 * *$ & 0.023 & $0.374 * *$ & $0.172 * *$ \\
\hline affiliation and multi-unit firm & $(0.058)$ & $(0.052)$ & $(0.053)$ & $(0.055)$ & $(0.054)$ \\
\hline 3. Adding union density & $\begin{array}{c}0.173 * * \\
(0.060)\end{array}$ & $\begin{array}{c}0.207 * * \\
(0.055)\end{array}$ & $\begin{array}{c}0.055 \\
(0.055)\end{array}$ & $\begin{array}{c}0.355^{* *} \\
(0.057)\end{array}$ & $\begin{array}{c}0.119 * * \\
(0.056)\end{array}$ \\
\hline $\begin{array}{l}\text { 4. Adding control for ability to evaluate work } \\
\text { performance }\end{array}$ & $\begin{array}{c}0.167 * * \\
(0.061) \\
\end{array}$ & $\begin{array}{c}0.198 * * \\
(0.055) \\
\end{array}$ & $\begin{array}{c}0.052 \\
(0.055)\end{array}$ & $\begin{array}{c}0.363^{* *} \\
(0.057) \\
\end{array}$ & $\begin{array}{c}0.123 * * \\
(0.056)\end{array}$ \\
\hline
\end{tabular}

Notes: * denotes significance at $10 \%, * *$ significance at $5 \%$. The standard errors are shown in parenthesis. The explanatory variables are explained in the notes to Table 1. 


\section{References}

Agell, J. and H. Bennmarker (2002), "Wage policy and endogenous wage rigidity: a representative view from the inside," IFAU Working Paper No. 2002:12.

Agell, J. and P. Lundborg (1995), “Theories of pay and unemployment: survey evidence from Swedish manufacturing firms”, Scandinavian Journal of Economics 97, $295-307$.

Agell, J. and P. Lundborg (2003), "Survey evidence on wage rigidity and unemployment: Sweden in the 1990s," Scandinavian Journal of Economics 105, 15-29.

Akerlof, G. (1980), “A theory of social custom, of which unemployment may be one consequence," Quarterly Journal of Economics 94, 749-775.

Akerlof, G. (1982), “Labor contracts as partial gift exchange,” Quarterly Journal of Economics 97, 543-569.

Albaek, K., M. Arai, R. Asplund, E. Barth, and E. Strøjer Madsen (1998), "Measuring wage effects of plant size," Labour Economics 5, 425-448.

Arai, M. (2001), "Wages, profits and capital intensity: evidence from matched worker-firm data," forthcoming, Journal of Labor Economics.

Blinder, A. and D. Choi (1990), "A shred of evidence on theories of wage stickiness," Quarterly Journal of Economics 105, 1003-15.

Bewley, T. (1999), Why wages don't fall during a recession. Harvard University Press, Cambridge (Ma.) and London, England.

Brown, C., J. Hamilton and J. Medoff (1990), Employers large and small, Harvard University Press, Cambridge (Ma).

Brown, C. and J. Medoff (1989), “The employer size-wage effect,” Journal of Political Economy 97, 1027-1059. 
Bulow, J. I. and L. H. Summers (1986), “A theory of dual labor markets, with application to industrial policy, discrimination, and Keynesian unemployment, "Journal of Labor Economics 4, 376-414.

Campbell, C. M. and K. S. Kamlani (1997), “The reasons for wage rigidity: Evidence from a Survey of Firms," Quarterly Journal of Economics 112, 759-89.

Encinosa, W. E., M. Gaynor and J. B. Rebitzer (1997), “The sociology of groups and the economics of incentives: theory and evidence on compensation systems," NBER Working Paper No. 5953.

Fehr, E. and S. Gächter (2002), "Do incentive contracts undermine voluntary cooperation?” Institute for Empirical Research in Economics, University of Zurich, Working Paper No. 34 .

Fehr, E., G. Kirchsteiger and A. Riedl (1993), "Does fairness prevent market clearing? An experimental investigation," Quarterly Journal of Economics 108, 437-459.

Fehr, E. and K. M. Schmidt (1999), “A theory of fairness, competition, and cooperation,” Quarterly Journal of Economics 114, 817-868.

Garen, J. E. (1985), “Worker heterogeneity, job screening, and firm size,” Journal of Political Economy 93, 715-739.

Gneezy, U. and A. Rustichini (2000), “A fine is a price,” Journal of Legal Studies 29, 1-18.

Groshen, E. L. (1991), “Five reasons why wages vary among employers,” Industrial Relations 30, 350-381.

Helper, S. (2000), "Economists and field research: 'you can observe a lot just by watching,," American Economic Review 90 (Papers and Proceedings), 228-232.

Holmstrom, B. and P. Milgrom (1994), “The firm as an incentive system,” American Economic Review 84, 972-992. 
Lazear, E. P. and S. Rosen (1981), "Rank-order tournaments as optimum labor contracts," Journal of Political Economy 89, 841-864.

Lazear, E. P. (1989), "Pay equality and industrial politics," Journal of Political Economy 97, $561-580$.

Oi, W. Y. and T. L. Idson (1999), "Firm size and wages," in Handbook of Labor Economics, volume 3A (eds. O. Ashenfelter and D. Card), Elsevier: Amsterdam.

Priks, M., 2003, "Why do cooperatives use egalitarian wage schedules", mimeo, Department of Economics, Stockholm University.

Shapiro, C. and J. E. Stiglitz (1984), "Equilibrium unemployment as a worker discipline device," American Economic Review 74, 433-444.

Stiglitz, J. (1975), "Incentives, risk and information: notes towards a theory of hierarchy," Bell Journal of Economics 6, 552-579.

Troske, K. R. (1999), ”Evidence on the employer size-wage premium from workerestablishment matched data," The Review of Economics and Statistics 81, 15-26. 